\title{
Hot Air: The Science and Politics of $\mathrm{CO}_{2}{ }^{1}$
}

\author{
Jens Soentgen
}

Abstract: $\mathrm{CO}_{2}$ is not a simple, immediately graspable substance like water, salt, or mercury. It has to be conceptually and instrumentally constructed since, as an air-like substance, $\mathrm{CO}_{2}$ is almost invisible and almost odorless, quickly diffuses into the surrounding air, and it is only through special instrumental apparatus (such as a pneumatic trough) or in hermetically sealed locations that it can be(come) sufficiently concentrated for it to be recognizable as a unique individual substance. This constructive work was carried out between the seventeenth and early nineteenth centuries. The older belief in the special status of "spirits" was displaced by the concept of gas - but only in laboratories. In public communication, "gases" continue to be emotionally charged substances that are in no way normal. Further investigation of the history of $\mathrm{CO}_{2}$ shows that the substance has been increasingly politicized and moralized since around the 1980s in the context of the climate change debate. Chemical $\mathrm{CO}_{2}$ is being reconstrued as a "pollutant" that threatens the earth and future generations.

\section{Mazuku - "Evil Wind"}

Lake Nyos is among the most beautiful of the crater lakes in western Cameroon's volcano region, formerly called the "good lake" by locals. During the night of 21 August 1986, however, something terrible happened, which the late American anthropologist Eugenia Shanklin later described from the perspective of a survivor:

\begin{abstract}
At SuBum, close to the village of Nyos, one man heard his 9-year-old daughter choking and he got up to go to her, but before he reached her room he fell unconscious onto the floor. When he awoke, dazed and sick, he crawled into bed beside her and only realized she was dead hours later ... There was a burning sensation in his lungs; he drank all the water and tinned milk in the house, then climbed on his motorcycle and made the $20 \mathrm{~km}$ ride to Wum. The road was littered with bloated human and animal carcasses. To pass, he had to move the bodies of friends and neighbors, but the worst part was the overwhelming silence: in one of the most fertile valleys of the volcanic uplands, an area well-stocked with bugs of every variety and vocal persuasion, not an insect remained. ${ }^{2}$
\end{abstract}

When Joseph Nkwain reached Wum, he found it full of the normal bustle of everyday business and

\footnotetext{
${ }^{1}$ This article was written in German and has been translated for Global Environment by Andrew Godfrey, as have all translations from German-language sources, unless otherwise noted. The introduction of this article (Mazuku ) has appeared previously in slightly different form in J. Soentgen, "On the History and Prehistory of $\mathrm{CO}_{2}$ ", in Foundations of Chemistry, 12, 2, 2010

2 E. Shanklin, "Beautiful Deadly Lake Nyos", in Anthropology Today, 4, 1, 1988, p. 12.
} 
nobody had any idea that there had been a catastrophe in nearby SuBum. Several policemen and a priest soon made their way to the little village on the lake, doubling back the way the survivor had come. In all the villages on the lakeshore there weighed an oppressive silence. Most of the houses were closed up. There was only motionless silence, as if it were still night time. In front of other houses dead families were crowded together. Later the priest, the Dutch missionary Father tenHorn, would say, it looked as if a neutron bomb had hit: "Little damage to property, but an almost total destruction of life." This remark would soon pass from mouth to mouth. ${ }^{3}$

However, investigations by European geologists come to a different conclusion: according to them it was a massive carbon dioxide bubble that rose from an underground magma chamber that had formed under the lake bed, and had finally, perhaps triggered by a mudslide, escaped, spreading out over the shore and killing people, animals, birds, and even insects. Altogether the catastrophe caused at least 1,765 deaths.

Carbon dioxide emissions occur in several places in Central Africa. Often they are referred to by the Swahili word mazuku, "evil wind". In the Nyos region scientific theories attributing the event to natural causes never really caught on. Instead, the disaster was attributed to lake spirits who were angered because the Europeanized residents of the region had neglected them. In particular, a female spirit called Mami Wata, who lived in the lake, was believed to have been associated with the catastrophe. The poet Bole Butake, shaken by the tragedy, even wrote a play with the title Lake God in which he explicitly refuted the notion that a gas could be responsible for the event, pleaded for a return to the old beliefs and demanded offerings be made to the water spirit. ${ }^{4}$ Another theory presented to explain the disaster held that the Israeli and US military, or perhaps European nations, had used Lake Nyos as the site of a neutron bomb test. ${ }^{5}$

The terrible events around Lake Nyos in Cameroon took place in the twentieth century. However, it provides a sense for the circumstances and locations in which people probably originally

\footnotetext{
${ }^{3}$ Ibid., pp. 12-14; id., "Exploding Lakes in Myth and Reality: An African Case Study", in: Myth and Geology, L. Piccardi, W.B. Masse (eds.), The Geological Society, London 2007, pp. 169-171; N.K. Sinjoh, Ten Years after the Lake Nyos Kisaster: Its Causes and Effects from the Bum Survivors' Perspective, University of Buea, Buea 1997, p. 22.

${ }^{4}$ B. Butake, Lake God, Bet \& Co (Pub.) Ltd., Yaounde 1986; L.T. Asong, "Bole Butake’s Lake God: A Prototypical Mythoeic Drama", Cameroon Tribune, 2 May 1987, p. 15. An interesting parallel to this framing is the "basilisk" legend in medieval and early modern Europe, also disseminated by intellectuals, which interpreted sudden death near or within carbon-dioxide rich wells or springs with the existence of a monster called the basilisk, that lives within caves and ponds and can kill people with his gaze. See the critical report of J.T. Tabernaemontanus, Neuw Wasserschatz. Frankfurt am Main 1584, p. 260; for a detailed examination of this legend, see M. Sammer, Der Basilisk: Zur Naturund Bedeutungsgeschichte eines Fabeltieres im Abendland, Literatur in Bayern, Munich 1998.

${ }^{5}$ Shanklin, "Exploding Lakes in Myth" cit., pp. 165-176.
} 
encountered $\mathrm{CO}_{2}$ and how they might have described these experiences. ${ }^{6}$ The local population's rejection of explanations that the catastrophe had been triggered by a gas shows that this interpretation is in no way obvious. ${ }^{7}$ In Europe, too, the concept "gas" is only around 350 years old, and the chemical framing of carbon dioxide (or carbonic acid, see below) date back only the end of the eighteenth century. Strictly speaking, the history of carbon dioxide is limited to these 200 or 300 years, and it is a history that is limited to the West. For many people in other areas of the world and probably for the majority of people living today - there are no "gases" and thus no carbon dioxide. They interpret their experiences according to a different framework, as the story of Lake Nyos in Africa has shown. The existence of the concept does not itself magically create the gas, however; without the concept and the theoretical framework in which it is embedded, it is impossible to experience it. Because concepts imply a certain perspective on the object, they also transform our sensory experience.

There are also widely divergent conceptions of what carbon dioxide is in industrialized nations. It's not simply a case of "laypeople" having a "simplified" conception of the substance. Rather, since at least the start of the climate debate, there have been various images and concepts of carbon dioxide, to which other symbols and expressions also partially correspond. They correspond to different commodity-chains and to different discourses. The $\mathrm{CO}_{2}$ of chemists is rather different from theCO2 of politicians and economists who focus on climate issues; it is also different from the "pollutant" that figures in public discussion. And when sparkling mineral water manufacturers or spa operators talk of "naturally carbonated water", they are talking about something else again. The battle lines are not drawn between those who argue scientifically and everyone else. Rather, both the climate skeptics, for whom $\mathrm{CO}_{2}$ is an "elixir of life" but not a "pollutant", and the balneologists, for whom it is a "healing gas", regard themselves just as much as scientists as those who warn of the climatic and ecological consequences of human $\mathrm{CO}_{2}$ emissions. The various concepts of carbon dioxide did not, as it were, simply develop peacefully alongside each other, but are, as we shall see, the occasion for fierce disputes. But the modern, highly divergent concept has developed from a single root, which I outline briefly before moving onto the dispute surrounding "hot air".

\section{Taming the "Wild Spirit": The Concept of Gas}

\footnotetext{
${ }^{6}$ On other sources of carbon dioxide in volcanic areas, see C.F. Naumann, Lehrbuch der Geognosie, Vol. 1, Wilhelm Engelmann, Leipzig 1849, pp. 299-302.

${ }^{7}$ Shanklin, "Exploding Lakes in Myth" cit., pp. 165-176.
} 
The term "gas" was introduced by the Flemish doctor, alchemist, and mystic Johann Baptist van Helmont; it appears for the first time in a collection of his writings called Ortus Medicinae, published posthumously in Amsterdam in 1648. He discusses his new theory most extensively in the treatise "Complexionum atque Mistionum Elementalium Figmentum" ("The Fiction of Elementary Complexions and Mixtures"), in which he describes his experiments heating charcoal in a closed vessel thus:

Therefore the live coal, and generally whatsoever bodies do not immediately depart into water, nor yet are fixed, do necessarily belch forth a wild spirit or breath. Suppose thou, that of 62 pounds of Oaken coal, one pound of ashes is composed: Therefore the 61 remaining pounds, are the wild spirit. .... I call this Spirit, unknown hitherto, by the new name of Gas, which can neither be constrained by Vessels, nor reduced into a visible body. ${ }^{8}$

The term "gas" at first seems unremarkable and not substantially different from the Stoic concepts of anathymiasis and pneuma that preceded it; indeed, the "wild spirit" gas is described in terms that still echo in the African mazuku four centuries later. However, it marks a qualitative shift in human understanding of the world and represents one of the most significant new concepts that arose during the modern period.

Although people had long spoken of "spirits" or "spiritus", these were always construed in relative terms, as "spirits of". People spoke, for instance, of the salt spirit, the niter spirit, the sulfur spirit. But in the theorizing that followed in the wake of van Helmont, gas was found to be a substance in its own right that did not need any basis in a concrete substance like table salt, niter, or sulfur that people could hold in their hands. The concept of gas came to be of central importance for the science of chemistry because it encompassed an entirely new category of substance, and these substances were both products of chemical reactions and agents in chemical reactions. Later, socalled pneumatic chemists also learned how to isolate these scarcely tangible substances, to weigh them and even to purify them. And as they became tangible and contained, they also became commodities: today we can buy $\mathrm{CO}_{2}$ for carbonating water or oxygen for welding just as we would buy sugar or wine.

Of course the earlier alchemists, chymists, and chemists had noticed that vapor or odors accompanied certain chemical reactions, but had not investigated it as a substance in its own right. Nor could they have, for they lacked the necessary equipment. Stephen Hales is considered the inventor of the pneumatic trough, which was originally intended to purify the air, but later was used

\footnotetext{
${ }^{8}$ J.B. van Helmont, Oriatrike, or, Physick Refined, J. Chandler (trans.), Lodowick Lloyd, London 1662, p. 106. First published in Latin: id., Ortus medicinae, Amsterdam 1652, p. 86.
} 
to collect different "types of air", that is, gases. ${ }^{9}$ Gradually scientists recognized that what they had considered "vapor" or "odors" were not accidental phenomena, but actual new substances that were just as fundamentally different from one another as mercury, table salt, and water.

The concept "gas", so neglected in the history of science, nevertheless opened a new horizon for the natural sciences and was of practically ontological significance. The novelty of the concept lies in the fact that it is counterintuitive: air normally appears as a homogenous mass in which it is difficult to distinguish any differences. In the long run, the concept objectivated the air, put it into the typical chemical perspective, insofar as it integrated it in a hylocentric and no longer anthropocentric view. Now, the breathability (or non-breathability) was no longer the essential property, but the position of the substance in the system of chemical transformations. The concept was a breakthrough for chemistry because (once again: in the long run) it enabled a systematic theory of the elements for the first time. All key chemical discoveries that followed, such as the law of the conservation of matter or the periodic table, are dependent on the concept of gas. And the first type of gas to be clearly identified was $\mathrm{CO}_{2}$.

Van Helmont was the first to regard the substance set free during heating or fermentation as something different from the surrounding air and from water vapor. ${ }^{10}$ At the same time, he did yet not see gases as simply substances like everything else; this only happened much later, at the turn of the eighteenth to the nineteenth century. Rather, van Helmont continued to believe that gas constituted the innermost principle of the body, something like its living spirit, which drives it from within. ${ }^{11}$ For this reason, he believed, gases could be especially dangerous to people, and he mentions explicitly the dangers lurking in fermentation cellars and in mining pits. Gas inhaled could kill much more quickly than poisoned food or drink, because, according to van Helmont's theory, they had a direct effect on the living spirit of a human being. And this was also the reason why it could only be forced into containers with great difficulty, and, van Helmont thought, could not be turned into a solid substance again. His gas thus still has something numinous about it; it is a relative of the Stoic pneuma, which the alchemists considered to be partially alive, at the very least

\footnotetext{
${ }^{9}$ M. Carrier, “Atome und Kräfte: Die Entwicklung des Atomismus und der Affinitätstheorie im 18. Jahrhundert und die Methodologie Imre Lakatos"”, unpublished dissertation, Westfälische Wilhelms-Universität zu Münster, 1984, pp. $151 \mathrm{ff}$.

${ }^{10}$ J. Soentgen, "On the History and Prehistory of $\mathrm{CO}_{2}$ " cit.; see also V. Mudroch, "Johann Baptista van Helmont", in Die Philosophie des 17. Jahrhunderts, vol. 1, Allgemeine Themen: Iberische Halbinsel, Italien, H.-P. Schobinger (ed.), Schwabe und Co, Basel 1998, p. 34ff.

${ }^{11}$ Van Helmont is using the Paracelsian concept of archeus, see J. Büchel, Psychologie der Materie: Vorstellungen und Bildmuster von der Assimilation der Nahrung im 17. und 18. Jahrhundert unter besonderer Berücksichtigung des Paracelsismus, Könighausen und Neumann, Würzburg 2005, p. 94ff.
} 
an inner driving force of the body. ${ }^{12}$ It thus takes on a special ontological status and is in no way just a substance among others.

\section{Lavoisier's Acide Carbonique and His Theory of Gases}

In the years following van Helmont's discovery, $\mathrm{CO}_{2}$ was often referred to as "mephitic air" or "fixed air". All of these names soon got caught up in the theoretical turmoil brought on by French chemist Antoine Laurent Lavoisier's “antiphlogistic chemistry”. In this new, and, as his contemporaries rightly saw it, revolutionary chemistry, the tax collector Lavoisier no longer explained combustion processes by positing an invisible substance called phlogiston that was ostensibly released during combustion, as had previously been the case, but rather suggested that combustion in fact involved a chemical synthesis in which oxygen is added. Lavoisier published this new theory as early as 1777 , but it only became generally accepted with the famous work Méthode de nomenclature chimique (Method of Chemical Nomenclature) that Lavoisier published together with his colleagues Hassenfratz, Guyton de Morveau, Adet, Fourcroy, and Berthollet, who were already supporters of his new theory. This work appeared in 1787, two years before the beginning of the French Revolution, and it introduced new names for many chemical substances names that were not simply new designations, but rather expressed the experiences that chemists had had with specific substances. ${ }^{13}$ This book, which occupies a singular place in the history of chemistry, also did away with the colorful names by which our invisible gas was known. In their place appeared a purely chemical designation that was based solely on the substance's chemical composition: l'acide carbonique, carbonic acid, although no distinction was made between the gas and its dissolved state in water. ${ }^{14}$ Acide carbonique, carbonic acid, is a name that not only assumes familiarity with laboratory experiments, but also a theory that unified any number of pieces of evidence. Therefore, while the name could be used by anyone, only a specialist could understand what it meant. The name interprets this special "kind of air" as not just a qualitatively degraded

\footnotetext{
${ }^{12}$ G. Verbeke, L'Évolution de la Doctrine du Pneuma du Stoicisme à S. Augustin: Étude Philosophique, Bibliothèque de L'Institut Supérieur de Philosophie, Université de Louvain, Louvain, Paris 1945, p. 340.

${ }^{13}$ E. Ströker, Theoriewandel in der Wissenschaftsgeschichte: Chemie im 18. Jahrhundert, Klostermann, Frankfurt am Main 1982, pp. 271-281.

${ }^{14}$ L.-B. Guyton de Morveau, A. Lavoisier, C.-L. de Berthollet, A.-F. de Fourcroy, Méthode de nomenclature chimique, Cuchet, Paris 1787, p. 149, translated into English by J. St. John as Method of Chymical Nomenclature, G. Kearsley, London 1788; see also A. Lavoisier, Traité elementaire de chimie, Paris 1789, p. 251, online at http://fr.wikisource.org/wiki/Trait\%C3\%A9_\%C3\%A91\%C3\%A9mentaire_de_chimie (accessed 14 October 2013), English translation: Elements of Chemistry, R. Kerr (trans.), William Creech, Edinburgh 1790, available at http://www.gutenberg.org/files/30775/30775-h/30775-h.htm.
} 
form of normal air that can be made into healthy air again by purifying it, but rather recognizes that it is a discrete, unique substance that has its own composition and was soon to even receive its own chemical formula.

Lavoisier's theory regarding the states of matter also contributed to the demystification of $\mathrm{CO}_{2} . \mathrm{He}$ postulated that all substances, not just water, can appear in three different physical states. ${ }^{15}$ Therefore, it should be possible to make substances that are normally gaseous into liquids or solids by changing the pressure and temperature. Gases, his theory argued pointedly, are thus not particularly spiritual substances, but actually liquids ${ }^{16}$ or solids that were prevented from becoming such. The first gas that was investigated in light of this theory was ammonia, which Martinus van Marum turned into a liquid in $1799 .{ }^{17}$ Carbonic acid was first liquefied by Jean Charles Thilorier and solidified as dry ice in $1835 .{ }^{18}$ The theory of states of matter completed the development of the modern concept of gas. Since that time chemists and students of chemistry have learned: there are such things as gases and they are substances like all others.

At the beginning of the nineteenth century, when Jöns Jakob Berzelius succeeded in creating a system of convention that permitted the notation of chemical substances, he also transformed carbon dioxide. He wrote: "The chemical sign expresses always one volume of the substance. When it is necessary to indicate several volumes, it is done by adding the number of volumes ... the sign ... for carbonic acid [is] C $+2 \mathrm{O} .{ }^{\prime 19}$ Because this notation was sometimes cumbersome, he conceded that it could also be abbreviated as $\mathrm{CO}^{2}$. Berzelius' proposal for a system of chemical notation was initially ignored, but in the course of the nineteenth century ultimately did manage to become established convention. ${ }^{20}$ Justus von Liebig used Berzelius' notation, but instead of superscripts used subscripts, ${ }^{21}$ a practice that finally became the accepted convention. So, after countless transformations, the symbolic form by which we know carbon dioxide today came into being: $\mathrm{CO}_{2}$.

\footnotetext{
${ }^{15}$ Lavoisier, Traité elementaire de chimie cit, p. 7. On "gas" in Lavoisier's theory, see T.H. Levere, "Lavoisier's Gasometer and Others: Research, Control, and Dissemination”, in Lavoisier in Perspective, Marco Beretta (ed.), Deutsches Museum, Munich 2005, p. 53-67 and the literature listed in that article.

${ }^{16}$ Carrier, "Atome und Kräfte" cit., p. 163.

${ }^{17}$ Ibid., p. 164.

${ }^{18}$ H.D Roller, "Thilorier and the First Solidification of a 'Permanent' Gas (1835). With Facsimile Reproduction (No. XXII) of Thilorier's Letter Announcing the Solidification of Carbonic Acid (Comptes Rendus, 1835, Vol. I, pp. 194196)", in Isis, 43, 1952, pp. 109-113.

19 J.J. Berzelius, "Essay on the Cause of Chemical Proportions, and on Some Circumstances Relating to Them; Together with a Short and Easy Method of Expressing Them", in Annals of Philosophy, 3, 1814, p. 51.

${ }^{20}$ U. Klein, Experiments, Models, Paper Tools: Cultures of Organic Chemistry in the Nineteenth Century, Stanford University Press, Stanford 2003, p. 14ff.

${ }^{21}$ Ibid., p. 178.
} 
Together with $\mathrm{H}_{2} \mathrm{O}, \mathrm{CO}_{2}$ is one of two chemical formulas that are popularly known worldwide. This formula no longer suggests any phenomenal properties; it doesn't even note that it is a gas! Instead of indicating physical properties, it locates the substance within the network of chemical transformations: The substance is framed as the product of an oxidation of carbon (or carboncontaining molecules). It is seen within the process-oriented, hylocentric chemical perspective.

With this formula the invisible, furtive, and rather uncanny laboratory guest was given an internationally valid identity that turned it into an ordinary substance within the modern system of chemical substances. It no longer has a special status because it is invisible; instead, it is merely one substance among many others. This divine, suggestive breath started as a spiritus, a partly natural, partly supernatural spirit, and finally became a gaseous substance, which, while it was handled with respect, was not essentially different than any other substance. At least in chemical theory.

However, if the preceding years had been, in spite of van Helmont's pioneering work, the "spiritual era" in the history of $\mathrm{CO}_{2}$, in the eighteenth century the era of rationalized $\mathrm{CO}_{2}$ was now beginning. Through being grasped conceptually as a gas and deprived of its special status, and through receiving a formula and a scientific name that classified it as one substance among others, it was ontologically leveled. The era of rationalized $\mathrm{CO}_{2}$ began with pneumatic chemistry in the mideighteenth century, even though the name "carbon dioxide" had not yet become settled by that point. Thanks to Joseph Priestley's discovery of the ecological significance of $\mathrm{CO}_{2}$ for the nutrition of plants (and hence also of animals and humans), this era yielded discoveries that still significantly shape the world picture of people in the West to this day. ${ }^{22}$

At the same time, the scientific rationalization and objectivization of carbon dioxide enabled its transformation into a commodity. Many chemists tried to imitate mineral waters, ${ }^{23}$ among them the pneumatic chemist Joseph Priestley, who invented a new and promising method of producing artificial soda water and published an advertising brochure. ${ }^{24}$ In the nineteenth century a series of technological innovations made it possible to produce liquid carbon dioxide on a large scale and

\footnotetext{
${ }^{22}$ Soentgen, "On the History and Prehistory of $\mathrm{CO}_{2}$ " cit.

${ }^{23}$ Sparkling water was first produced by the combination of potash and sulfuric acid by Friedrich Hoffmann; see F. Hoffman, New Experiments and Observations upon Mineral Waters, 2nd ed., T. Longman, London 1743, p. 190. On the history of artificial mineral waters see B.M. Lersch, Geschichte der Balneologie, Hydroposie und Pegologie; oder des Gebrauches des Wassers zu religiösen, diätetischen und medicinischen Zwecken, Stahel, Würzburg 1863, p. 223226.

${ }^{24}$ J. Priestley, Directions for Impregnating Water with Fixed Air, in Order to Communicate to It the Peculiar Spirit and Virtues of Pyrmont Water, London 1772.
} 
store it in steel cylinders. ${ }^{25}$ Sparkling water could be produced and sold wherever the consumer demanded it. -Thus, the monopoly of spa towns could be lifted. Artificial soda water was the first practical application of carbon dioxide ${ }^{26}$ and even today it is still the most important by a significant margin. Naturally carbonated water, that is to say water with a high carbon dioxide content, had always been regarded as having special healing properties in virtue of the "spirit" that it contained. ${ }^{27}$

For this reason, earthenware jugs filled with mineral water from spa towns such as Bad Pyrmont were traded across Europe. It was now possible to create "artificial Pyrmont water" out of any normal drinking or table water by adding pure carbon dioxide. Like many of his contemporaries, Priestley believed that such "artificial Pyrmont water" could even cure scurvy and recommended it to the English Admiralty to this end. ${ }^{28}$

Both carbon dioxide from natural sources and extremely pure carbon dioxide produced during certain large-scale chemical processes (such as the Haber-Bosch process) are used to manufacture carbonated water and soft drinks. Today, soda water manufacturers in German-speaking countries still usually list "Kohlensäure" (carbonic acid) as an ingredient rather than "Kohlendioxid" ("carbon dioxide"), changing this to "naturally occurring carbonic acid" if the substance comes from a natural source, while in English it is usual to list "carbonated water" (or "naturally carbonated water"). This keeps the disruptive influence of the climate debate at a safe distance from the "healthy and "natural" beverage ${ }^{29}$. This has proved successful, as carbon dioxide isn't regarded as a

\footnotetext{
25 J.C. Goosmann, The Carbonic Acid Industry: A Comprehensive Review of the Manufacture and Uses of $\mathrm{CO}_{2}$, Nickerson \& Collins, Chicago 1907; N. Wender, Die Kohlensäure-Industrie, M. Brandt, Berlin 1901. E. Kahl, Die Deutsche Kohlensäure-Industrie vom Standpunkt der Standortslehre, J.C.B. Mohr, Tübingen 1921.

${ }^{26}$ In addition to the uses in carbonated water and other soft drinks, there are now many other technical applications of carbon dioxide. See the overview by F. Grünberg, "Düngen, Kühlen, Reinigen $-\mathrm{CO}_{2}$ in der Technik", in $\mathrm{CO}_{2}-$ Lebenselixier und Klimakiller, J. Soentgen, A. Reller (eds.), Oekom, Munich 2009, pp. 65-77.

${ }^{27}$ Hence, Tabernaemontanus said of healing water: "its power [resides] only in the spirits or spiritibus". These alone made water into a remedy "especially for internal physical ailments". Tabernaemontanus, Neuw Wasserschatz cit., p. $16 f$.

${ }^{28}$ Priestley, Directions for Impregnating Water cit.; see also R. Schofield, The Enlightenment of Joseph Priestley, Pennsylvania State University Press, University Park 1997, pp. 256-258.

${ }^{29}$ On the ideology of pure water, see R. Wilk, "Bottled Water: The Pure Commodity in the Age of Branding", in Journal of Consumer Culture, 6, 3, 2006, pp. 303-325.
} 
pollutant in spa towns but on the contrary is recommended by doctors as a "healing gas", ${ }^{30}$ and moreover neither manufacturers of carbonated water nor health spas are required to obtain emissions certification for the gas that they release, even though the quantities of $\mathrm{CO}_{2}$ that they require, and hence release, are substantial. ${ }^{31}$

\section{“Gas" beyond the Laboratory}

The chemical concept of gas that has provided the standard across the natural sciences since its definitive formulation by Lavoisier is hylocentrically defined, i.e., the concept is conceived as a "state" of the substance. According to the Grimms' dictionary of German, at the end of the eighteenth century the concept spread "from the laboratories to the people". ${ }^{32}$ When it crossed this social and epistemic boundary, its meaning changed.

Ludwig Fleck first explicitly discussed changes in meaning of this kind in the context of the philosophy of science: "From specialist (esoteric) knowledge there emerges popular (exoteric) knowledge. It appears, thanks to its simplification, clarity, and apodicticity, to be secure, rounded off, firmly established." ${ }^{33}$ This famous characterization is, of course, itself simple, clear, and apodictic and thus persuasive, especially in its culmination, whereby the knowledge formed through this process is in turn fed back to the specialists. Yet the case of carbon dioxide does not support Fleck's characterization. It is true, as the following investigations show, that the knowledge embodied in the concept of carbon dioxide changes when it leaves the laboratory. But this change

\footnotetext{
${ }^{30}$ As early as the nineteenth century: see Friedrich August II (King of Saxony), J.W. von Goethe, K.J. Heidler, Pflanzen und Gebirgsarten von Marienbad, ergänzt, und mit einem Anhange über die andern naturhistorischen Verhältnisse des Curortes, Kronberger und Weber, Prague 1837, p. 175. Even today, the "healing gas" carbon dioxide is praised on the websites of traditional spas such as Bad Pyrmont: "Many spa guests have been able to experience with their own bodies that it ... is a healing gas. The Pyrmont spa offers $\mathrm{CO}_{2}$ natural spring gas therapy for the following indications: peripheral circulation disorders, hypertonia and coronary insufficiency, allergy-related conditions (asthma, eczema); poorly healing wounds." (http://www.staatsbad-pyrmont.de/index2.php?href=main\&area=natur\&link=dunsthoehle; accessed 3 December 2013)

${ }^{31}$ The carbonated spring in Bad Driburg, one of many in Germany alone, "provides" 140,000 metric tons of $\mathrm{CO}_{2}$ a year. Personal communication from Peter-Wilhelm Koziel at Linde Gas, 14.7.2008.

${ }^{32}$ J. Grimm, W. Grimm, Deutsches Wörterbuch, Vol. 4, Erste Abtheilung, Erste Hälfte, Verlag von S. Hirzel, Leipzig 1878 , column 1428 .

${ }^{33}$ L. Fleck, Entstehung und Entwicklung einer wissenschaftlichen Tatsache: Einführung in die Lehre vom Denkstil und Denkkollektiv, Suhrkamp, Frankfurt am Main 1980, p. 150. The philosopher Essler is repeating a common view among scientific theorists when he claims that "everyday language" is "a peculiar conglomeration of fossils of old and dead theories": W.K. Essler, Wissenschaftstheorie I: Definition und Rekursion, 2nd ed., K. Alber, Freiburg 1982. Here, too, a degradation model is being applied that cannot be substantiated - at least not with regards to $\mathrm{CO}_{2}$. When scientific concepts migrate to the everyday world, they aren't simply mechanically pared down nor do they become fossils, but rather are reshaped and recentered and not just reduced but also enriched.
} 
does not consist primarily in simplification and rounding off but above all in a recentering. From a hylocentric perspective, it is relocated in a new way into an anthropocentric view. People reconceive the objectivized concept and it is thus both contracted and expanded.

"Gas" and " $\mathrm{CO}_{2}$ " mean something different outside of laboratories and lecture halls than they do inside. On the outside, their meaning is not based on a perspective focused on the substances and their transformations, but on immediate bodily experiences of the designated substances and public narratives and images.

For non-chemists, there is something uncanny about gases, despite their many positive applications such as gaslights or gas stoves. Likewise, the chemical classification of $\mathrm{CO}_{2}$ did not completely and universally rationalize and objectivize it in a single stroke, especially not from a global perspective. Even in the West it has retained aspects of a "wild spirit" in public consciousness. In this context, "gas" is primarily something threatening because it is invisible or scarcely visible, spreads very rapidly, and can be highly dangerous. The hiss of escaping gas sounds unsettling and recalls the hissing of an angry snake. For non-chemists, gases are one thing above all: dangerous. This anthropocentric concept of gas - conceived from the perspective of humans rather than substances and their transformations - is not as neutral and objectivized as the chemical concept: it sees in "gas" above all a threat that is hard to grasp. This concept became laden with additional negative connotations during the first half of the twentieth century in particular due to the horrific acts of "chemical warfare" involving gas in the First World War and the "gassing" of prisoners carried out in extermination camps by the National Socialist regime. Since this period, the terrifying image of the gas mask, which gives the human face an insect-like aspect, has always been present below the surface of the public concept. ${ }^{34}$

Chemical formulations as such have also had negative connotations and tend to be viewed something unnatural and harmful since around the $1970 \mathrm{~s} ; \mathrm{CO}_{2}$ is no exception. This change in meaning during the transition away from the laboratory must be taken into account when we turn to the next era in the social life of the substance.

This era first took form in laboratories and lecture halls, but quickly reached the public arena: carbon dioxide became recognized as a greenhouse gas. After the increasing concentration of

\footnotetext{
${ }^{34}$ See the excellent study by C. Glass, "Gas", in 13 Dinge: Form, Funktion, Bedeutung, Museum für Volkskultur in Württemberg, Stuttgart 1992, pp. 189-208. Studies in the didactics of chemistry also show that the original concept of gas had negative connotations, see J. Weerda, "Zur Entwicklung des Gasbegriffs beim Kinde", in Naturwissenschaften im Unterricht, Physik und Chemie, 29, 1981, pp. 90-98, especially p. 91.
} 
carbon dioxide in the atmosphere was discovered in the second half of the twentieth century and, moreover, global warming was actually measured and designated as a problem, carbon dioxide became a central topic of worldwide political discussion: a worldwide topic because it is being released everywhere through the burning of fossil fuels, on land, on water, and in the air; because as a gas it doesn't just spread regionally or locally like a solid or liquid, but diffuses equally throughout the entire atmosphere; and because the effects of global warming are also global in scale, even if in some places these effects are less negative or even positive.

Since around the 1980s, no other substance has been the topic of so much dispute and disagreement around the world; this era marks the politicization of $\mathrm{CO}_{2}$.

\section{Greenhouse Gas}

As early as 1800 , Jean-Baptiste Fourier argued that the atmosphere had a heat-trapping effect. ${ }^{35}$ His ideas were developed by Claude Pouillet and John Tyndall. The theory quickly became known as the greenhouse effect, because the basic supposition was that the atmosphere had an effect on radiation (not on convection) similar to the glass of a greenhouse. The atmosphere lets the visible thermal radiation of sunlight through, but the "dark heat" emitted from the surface cannot pass through the atmosphere and is reflected back. ${ }^{36}$ In this process, molecules with more than two atoms, such as $\mathrm{CO}_{2}$, water vapor, ozone, and various halocarbons play the central role. At a later date, the Swedish chemist Svante Arrhenius carried out rough calculations that gave plausibility to the idea that $\mathrm{CO}_{2}$ could also have climatic effects on the atmosphere as a greenhouse gas. ${ }^{37}$ In doing so, he established that burning fossil fuels, especially coal, would constantly increase the level of $\mathrm{CO}_{2}$ in the atmosphere, which would result in warming. His teachings were widely disseminated

\footnotetext{
${ }^{35}$ J.B. Fourier, "Extrait d'un mémoire sur le refroidissement séculaire du globe terrestre", in Oevres de Fourier, M. Gaston Darboux (ed.), Gauthier-Villars, Paris 1888, pp. 271-273; see also id., "Mémoire sur les températures du globe terrestre", in Oevres de Fourier cit., pp. 97-111.

${ }^{36}$ S. Arrhenius, Das Werden der Welten, Akademische Verlagsgesellschaft, Leipzig 1907; English translation: Worlds in the Making, H. Borns (trans.), Harper, London 1908, p. 51f.

${ }^{37}$ S. Arrhenius, "On the Influence of Carbonic Acid in the Air upon the Temperature of the Ground", in The London, Edinburgh, and Dublin Philosophical Magazine and Journal of Science, 41, 1896, pp. 237-276; id., "Über die Wärmeabsorption durch Kohlensäure und ihren Einfluss auf die Temperatur der Erdoberfläche", in Öfversigt af Kongliga Vetenskaps-Akademiens förhandlingar, 58, 1901/1902, pp. 25-48; see also E. Crawford, Arrhenius: From Ionic Theory to the Greenhouse Effect, Science History Publications, Canton (MA) 1996; see also the detailed study by N. Ekholm, "On the Variations of Climate", in Quarterly Journal of the Royal Meteorological Society, 27, 1991, pp. 162.
} 
during the early twentieth century, in particular through his work Worlds in the Making. ${ }^{38}$ Arrhenius saw something positive in the warming resulting from the release of $\mathrm{CO}_{2}$ :

We often hear lamentations that the coal stored up in the earth is wasted by the present generation without any thought of the future. ...We may find a kind of consolation in the consideration that here, as in every other case, there is good mixed with the evil. By the influence of the increasing percentage of carbonic acid in the atmosphere, we may hope to enjoy ages with more equable and better climates, ages when the earth will bring forth much more abundant crops than at preset, for the benefit of rapidly propagating mankind. ${ }^{39}$

This assessment on the part of the chemist became a minority opinion in later climate debate.

In climate research, $\mathrm{CO}_{2}$ theory as a way of explaining observable climate fluctuations was regarded as just one causal hypothesis among many until late in the 1970s. In his Introduction to Paleoclimatology, published in numerous editions, Martin Schwarzbach writes critically, repeating what appears to have been a common opinion: "Around the turn of the century, the "carbon dioxide hypothesis', for which S. Arrhenius sought to provide a physical justification and F. Frech sought to provide a geological one, enjoyed great renown ... However, investigation of the physical basis of their theories showed that only very small climate fluctuations could be caused in this manner." 40 Accordingly, Schwarzbach does not discuss the hypothesis when he "looks ahead" to future climate change, but instead considers the possibility of a coming ice age. ${ }^{41}$

Nevertheless, belief in the significance of the greenhouse gas hypothesis gradually attracted more support. The carbon dioxide curve measured by Charles David Keeling at the Mauna Loa Observatory in Hawaii showed a constant increase in levels of the trace gas; the Keeling Curve plays a significant role in the history of global warming. ${ }^{42}$ Because it was known that $\mathrm{CO}_{2}$ is a greenhouse gas and it could now be seen that its concentration was increasing, it became plausible that the global average temperature was also rising. Gradually, the hypothesis that $\mathrm{CO}_{2}$ was causing

\footnotetext{
${ }^{38}$ Arrhenius, Worlds in the Making cit., pp. 51-63.

${ }^{39}$ Ibid., p. 63.

${ }^{40}$ M. Schwarzbach, Das Klima der Vorzeit: Eine Einführung in die Paläoklimatologie, Ferdinand Enke Verlag, Stuttgart 1950, p. 173; even in later editions he remained skeptical despite a more sympathetic treatment of the $\mathrm{CO}_{2}$ theory; id., Das Klima der Vorzeit: Eine Einführung in die Paläoklimatologie, 3rd ed., Ferdinand Enke Verlag, Stuttgart 1974, pp. 286-291. Also available in English as Climates of the Past: An Introduction to Paleoclimatology, R.O. Muir (trans.), Van Nostrand, London, 1963. On Frech's theory about $\mathrm{CO}_{2}$, see F. Frech, "Studien über das Klima der geologischen Vergangenheit", in Zeitschrift der Gesellschaft für Erdkunde, 1902, pp. 611-693; id., "Über das Klima der Geologischen Perioden", in Neues Jahrbuch für Mineralogie, Geologie und Paläontologie, 1908, pp. 74-86; see also J. F. Pompeckj, "Über Fritz Frech”, in Neues Jahrbuch für Mineralogie, Geologie und Paläontologie, 1919, pp. 1-38.

${ }^{41}$ Schwarzbach, "Das Klima der Vorzeit" cit., p. 192.

${ }^{42}$ On Keeling, see S.R. Weart, The Discovery of Global Warming, Harvard University Press, Cambridge (MA) 2003, pp. 35-38.
} 
global warming became not just a scientific but also a public topic. In 1988, the International Panel on Climate Change (IPCC) was founded. ${ }^{43}$ This date marks the beginning of a new phase in the history of $\mathrm{CO}_{2}$. Until this point, $\mathrm{CO}_{2}$ had only been a scientific, a balneological, and (as "carbonic acid" for carbonated drinks and other applications) a scientific-technical topic. ${ }^{44}$ Now it was a disputed political substance. The IPCC published assessment reports in 1990, 1995, 2001, and 2007. The fifth assessment report was published at the end of 2013. The IPCC has pressed home the view that anthropogenic $\mathrm{CO}_{2}$ is the main cause of observed global warming, which is increased by the rising $\mathrm{CO}_{2}$ levels, and moreover that the warming has overwhelmingly negative consequences, so that its cause should be combatted. This causal diagnosis and evaluation are so controversial because they problematize the foundations of industrialized society. Now $\mathrm{CO}_{2}$ is, of course, a natural gas, produced through geological processes (volcanoes) and natural ones (animal and plant respiration, microbial decomposition). Ecologically, moreover, $\mathrm{CO}_{2}$ is the mobile phase of the carbon cycle and of central importance because it provides important nutrients for plants. So far, so good; there is little here that would seem to give cause for concern or debate.

However, in addition to the $\mathrm{CO}_{2}$ produced by nature itself, humans as the makers of fire also produce $\mathrm{CO}_{2}$. This $\mathrm{CO}_{2}$ is not simply a harmful by-product of combustion processes that could be filtered out with a little effort, like soot or $\mathrm{SO}_{2}$, but rather their main product: no less than the raison d'être of every fire. Wood, coal, natural gas, and crude oil are burned in order to transform them into $\mathrm{CO}_{2}$. Back when only biomass was burned (i.e., wood, straw, etc.), the only $\mathrm{CO}_{2}$ that was released into the atmosphere was that which the plants had absorbed a short while before, and so the $\mathrm{CO}_{2}$ levels in the air remained stable for thousands of years during the Holocene era at approximately 0.028 percent. Following the Industrial Revolution in Europe in the eighteenth century, increased quantities of $\mathrm{CO}_{2}$ have been produced since the transition to using fossil fuels such as coal, lignite, crude oil, and natural gas. This was linked to a shift from a solar energy regime to a fossil energy regime. ${ }^{45}$ Since that time, the burning of "fossil fuels" has formed the basis of industrial economies across almost the entire globe. This involves mobilizing and releasing into the atmosphere carbon that had been removed from the biological cycle and buried in fossil sediments. Since the start of the Industrial Revolution, there has consequently been a net increase of $\mathrm{CO}_{2}$ in the atmosphere, with concentrations currently standing at 0.04 percent and set to rise further. The only

\footnotetext{
${ }^{43}$ Ibid., pp. 155-159.

${ }^{44}$ F. Grünberg, “Düngen, Kühlen, Reinigen” cit., pp. 65-77.

${ }^{45}$ R.-P. Sieferle, "Sonne und Feuer - Energieregimes in historischer Perspektive", in Soentgen, Reller, $\mathrm{CO}_{2}-$ Lebenselixier cit., pp. 93-115.
} 
serious way to stop this increase would be to replace fossil energy production with other forms of energy production, such as nuclear energy or renewable forms of energy, and to simultaneously capture and store $\mathrm{CO}_{2}$ produced through the burning of fossil fuels, which not only would cause tumultuous social conflicts regarding the locations of the storage sites but would also result in an enormous increase in energy prices. This would be tantamount to dramatically changing the entire nature of industrial economies. All this explains why disputes about $\mathrm{CO}_{2}$ across the world are so intense. For this reason, $\mathrm{CO}_{2}$ (or $\mathrm{CO} 2$, as we shall shortly see) is not just a formula but also a code. It is the heading under which disputes are conducted concerning what kind of society we want to live in, and what kind of economy and environment we want.

The explosive nature of this topic is especially tangible in a text published by the German Advisory Council on Global Change (WBGU), "A Social Contract for Sustainability"46, which insists that climate protection should become the highest goal for political activity, since this is "a conditio sine qua non for sustainable development: although climate protection alone cannot guarantee the conservation of the natural life-support systems on which humanity depends, it is nevertheless foreseeable that without effective climate protection, mankind will soon have to do without some essential development opportunities." ${ }^{47}$ So climate protection isn't everything, but without climate protection everything is nothing: that's what the authors seem to want to say. In any case, these sorts of statements have pushed climate protection up the agenda when it comes to prioritizing goals. According to the WBGU, there is a "global political consensus that rapid global warming by more than $2^{\circ} \mathrm{C}$ would overtax our societies' ability to adapt". ${ }^{48}$ Correspondingly, the council regards the "decarbonization of the global energy system" as the most important goal of current political activity: "Normatively, the carbon-based economic model is also an unsustainable situation, as it endangers the climate system's stability, and therefore the natural life-support system for future generations. The transformation towards a low-carbon society is therefore as much an ethical imperative as the abolition of slavery and the condemnation of child labor." ${ }^{49}$ For this reason, climate protection and reduction of carbon dioxide emissions should be accorded the status

\footnotetext{
${ }^{46}$ Wissenschaftlicher Beirat der Bundesregierung Globale Umweltveränderungen (German Advisory Council on Global Change, WBGU), World in Transition: A Social Contract for Sustainability, Summary for Policy-Makers, WBGU, Berlin 2011, available at http://www.wbgu.de/fileadmin/templates/dateien/veroeffentlichungen/hauptgutachten/jg2011/wbgu_jg2011_kurz_en.pd f.

${ }^{47}$ WBGU, World in Transition cit., p. 2.

${ }^{48}$ Ibid., p. 2.

${ }^{49}$ Ibid., p. 1.
} 
of state goals. ${ }^{50}$

Of course, these demands are far removed from political reality; even in Germany, where even the conservative parties want to combat global warming. But they nonetheless clearly show just how weighty are the topics that are being negotiated under the code of carbon dioxide. If carbon dioxide is dangerous, then the foundations of our economies are also in danger, because almost all the activities that we carry out every day as producers or consumers in a modern technological civilization are linked to the production of carbon dioxide: from turning the ignition key in our cars to checking our email. The only reason we don't notice this is that the location where the carbon dioxide is released is closed-off and often many kilometers away from us.

\section{$\mathrm{CO}_{2}$ and $\mathrm{CO} 2$}

Following in the footsteps of the concept of gas, carbon dioxide has also, as Grimm put it, spread "from the laboratories to the people" 51 as a result of the climate debate. As a "greenhouse gas" it has thus become a risky and political substance. Climate change and anthropogenic $\mathrm{CO}_{2}$ have been on the political agenda since the 1980s. Aside from the well-documented presence of the topic in the media, its importance is evidenced in particular by the sensational awarding of the Nobel Peace Prize to Al Gore (who had been campaigning on the issue for years) ${ }^{52}$ and the IPCC in 2007.

In the intervening years, $\mathrm{CO}_{2}$ has consequently virtually become a threatening supernatural power in public communication in Europe and the USA. On the basis of the anthropocentric concept of gas characterized earlier, carbon dioxide is perceived as a dangerous gas. Not that it is seen as being remotely dangerous in low concentrations, else carbonated water would be banned: rather, it is its assumed effect on the global climate that is regarded as harmful. Because of global warming, which according to the IPCC is primarily caused by anthropogenic carbon dioxide, many authors are of the opinion that we are faced with the prospect of global environmental crises, or even with climate wars or the downfall of civilization. ${ }^{53}$

\footnotetext{
${ }^{50}$ Ibid., p. 10

${ }^{51}$ J. Grimm und W. Grimm, Deutsches Wörterbuch cit., column 1428.

${ }^{52}$ A. Gore, An Inconvenient Truth: The Planetary Emergency of Global Warning and What We Can Do about It, Rodale Press, New York 2006.

${ }^{53}$ H. Welzer, Klimakriege: Wofür im 21. Jahrhundert getötet wird, Fischer, Frankfurt am Main 2012. On the disaster stories connected with climate change, see also P. Pansegrau, "Treibhausgas, Klimakiller, CO2-Keule - Die mediale
} 
It was precisely carbon dioxide's apparent featurelessness and the general lack of any experience of the gas that qualified it to be loaded with semantic significance from the moment it crossed the epistemic barrier of the laboratory and lecture hall and became a topic for political and public dispute as the symbol of climate change. And at the same time, as a result of its formula, the systematic classification of its physical characteristics, and its chemical reactivity, it is clearly quantifiable, whether in tons or gigatons. It is precisely for this reason that it can be readily integrated with all social functional systems.

In public discussion, and thus also in large swathes of the political debate, $\mathrm{CO} 2$ has long ceased to be just a chemical substance, but has become a moral substance too: a natural, unnatural substance. $\mathrm{CO} 2$ is the evil totality, the sum of all transgressions, the confluence of all the environmentally harmful acts across the world, the point where they merge seamlessly into one, burdening us and our descendants. Whether it's another hectare of virgin forest being burned in Mato Grosso in Brazil or ten airplanes taking off in Frankfurt am Main - the ecological damage is transported into the air in the form of tons of $\mathrm{CO} 2$, diffused worldwide, and imposed as a climate burden on today's generation and generations to come. The call to reduce $\mathrm{CO} 2$ emissions now overshadows all other political goals relating to the environment.

As these considerations suggest, $\mathrm{CO}_{2}$ and $\mathrm{CO} 2$ are in no way identical. Rather, the slight typographical difference indicates a dramatic split in the concept of carbon dioxide, alongside which the previously discussed conceptual shifts appear insignificant. It indicates a politicization that affects the whole. That is to say: $\mathrm{CO}_{2}$, carbon dioxide, is a clearly defined chemical substance. The formula has clear, predefined semantics.

Political CO2, however, is the chemical substance seen from the perspective of the battle against global climate change. It is similar to the popular concept of gas and construed to a greater extent from the perspective of humans, namely as a substance that threatens them. It is an evaluated substance, since anthropogenic CO2 is above all simply "bad". When people talk in public discourse of a "climate poison" that is "tainting the environment", 54 it becomes clear that something different is meant than $\mathrm{CO}_{2}$ in a purely chemical and scientific sense. What is meant, rather, is a gaseous substance released through industrial processes and the burning of fossil fuels which is the primary cause of the global warming measured to date (and categorized as dangerous) and which must therefore be combatted.

Karriere des $\mathrm{CO}_{2}$, in Soentgen, Reller, $\mathrm{CO}_{2}$ - Lebenselixir cit., pp. 137-149.

${ }^{54}$ Pansegrau, “Treibhausgas, Klimakiller, $\mathrm{CO}_{2}$-Keule”, cit, p. 137. 
Political $\mathrm{CO} 2$ is not just a simplification or abbreviation of chemical $\mathrm{CO}_{2}$, but instead has many properties that the latter lacks. In particular, it hangs together with the fundamental demand for the creation of a new energy foundation for industrial society, which is not exactly something one can assert of the chemical concept of $\mathrm{CO}_{2}$. Chemically, it makes no sense, but politically, it makes perfect sense. In addition to "normal" political $\mathrm{CO} 2$, there are also the "CO2 equivalents". These also lack a chemical counterpart: they were devised by the IPCC in order to integrate other anthropogenic trace gases with an effect on the climate, such as methane, CFCs, and ozone, into the political and economic reduction efforts. Hence, for example, a metric ton of methane is "equivalent" to 21 metric ton of $\mathrm{CO} 2$ in terms of its climate impact. The most important institution in European climate politics, the European Union Emissions Trading System, grants emissions allowances, given in terms of $\mathrm{CO} 2$ equivalents, which during the third and currently ongoing trading period of the European Union Emissions Trading System take account of nitrous oxide, $\mathrm{N}_{2} \mathrm{O}$, and certain perfluorocarbons, or PFCs, from aluminum production alongside $\mathrm{CO} 2^{55}$.

In another respect, the scope of the political concept of $\mathrm{CO} 2$ is more restricted than that of the chemical concept, because a considerable portion of the $\mathrm{CO}_{2}$ released by human activity is not counted as political $\mathrm{CO} 2$. For instance, $\mathrm{CO}_{2}$ as a "by-product of reactions", such as that produced in millions of metric tons per year in Europe through the Haber-Bosch process, and which is often recycled in "carbonated" soft drinks, has not been transformed into political $\mathrm{CO} 2$. This kind of $\mathrm{CO}_{2}$ still doesn't require certification. The "carbonic acid" of carbonated water manufacturers and spas has also not been transformed into political $\mathrm{CO} 2$.

Whereas carbon dioxide, seen in chemical perspective, is written as $\mathrm{CO}_{2}$ (with a subscript), in political and moral discourses it often appears without, as $\mathrm{CO} 2$, and this is often a good way to distinguish between them. Of course, there's no official orthography, but the distinction has nonetheless taken root. $\mathrm{CO} 2$ is quicker to write than $\mathrm{CO}_{2}$ and the subscript is unnecessary for nonchemists, since the need that chemists have to distinguish between subscript and normal figures in their formulas does not apply in political discourse. This makes CO2 into a commodity once again a negative one that nobody wants. Some of the industries who release carbon dioxide or certain other greenhouse gases as a by-product of their operations now require appropriate authorization. Many others, like the producers of natural carbon dioxide, do not, although they directly drill the earth in order to release the gas.

\footnotetext{
${ }^{55}$ European Union Publication Office, The EU Emissions Trading System (EU ETS), 2013.
} 
Legal titles for CO2 emissions are currently traded in Europe on the European Energy Exchange (EEX) in Leipzig. The EEX, which is intended as a model for a hypothetical global exchange, has been running since the start of 2005. Emissions trading also takes place, or is set to be implemented soon, in New Zealand, Quebec, South Korea, and California. ${ }^{56}$ In these contexts, CO2 has been turned into what environmental economists call a "negative externality" as a result of political decisions. Besides the traditional commodity chain of real liquid carbon dioxide, there now exists a second, inverse commodity chain dealing with emission certificates for $\mathrm{CO} 2$. The different notions of carbon dioxide correspond to these two chains. Many companies which produce it in the course of their industrial production cannot earn money from it but must instead pay for an emissions certificate in the corresponding amount. This is an economic policy with the goal of reducing $\mathrm{CO} 2$ emissions.

$\mathrm{CO} 2$ "trading" takes place in everyday life too, independently of the EEX. In addition to the CO2 wholesale market, there is also a kind of $\mathrm{CO} 2$ retail market, and it is this which has made the formula famous. Ingenious businesspeople came up with the conceit of "compensating for" or (in more advertising-friendly terms) "neutralizing" "CO2 emissions", which are associated with individual activities such as driving or flying. This makes it possible to offer people the option of living a "carbon-neutral" ("CO2-free") life without making any changes.

To have this life, you just have to pay a little extra, and a new service industry lives off this surcharge, skillfully combining two commodity flows: on the one hand, promoting the sales of regenerative energy systems that reduce $\mathrm{CO} 2$ in poorer countries while on the other, boosting the sales of $\mathrm{CO} 2$-intensive products by rendering them $\mathrm{CO} 2$-free, and hence more attractive, at the cost of a surcharge. In this way, the industry brings about the logical miracle of $\mathrm{CO} 2$-free $\mathrm{CO}_{2}$.

\section{$\mathrm{CO}_{2}$ in Climate-Skeptic Discourse}

In the course of its moralization and politicization, the concept of $\mathrm{CO} 2$ has been recentered, changed its extension, and charged with values and emotion. Extreme examples help illustrate this trend: for instance, in its campaign for its "CO2-free" meat, the company "Ökoland" had a "super sausage" from its range do battle against the evil "CO2 monster". ${ }^{57}$ The British government also

\footnotetext{
${ }^{56}$ For an excellent overview, see R.G. Newell, W.A. Pizer, D. Raimi, "Carbon Markets 15 Years after Kyoto: Lessons Learned, New Challenges”, in Journal of Economic Perspectives, 27, 2013, pp. 123-146.

57 Ökoland, Superwurst rettet die Welt, 2013, http://www.oekoland.de/superwurst (accessed 10 October 2013).
} 
showed a "CO2 monster" as part of a TV campaign to educate children. ${ }^{58}$

Climate skeptics criticize the simplification that results from the politicization of $\mathrm{CO} 2$. They argue from alternative causal diagnoses, if they accept the existence of global warming at all. The media battle of climate skeptics against the established causal diagnosis of global warming might be, in terms of scale, the most significant public controversy about a scientific theory since the end of the Second World War. It can readily be compared to the dispute over Darwin's theory of evolution. Although the theory of global warming doesn't question the foundations of Christian faith, it does question the foundations of modern industrialized society - namely, its energy sources - and is therefore similar in certain essential features.

Climate skeptics argue that the problematization of the use of fossil fuels lacks any basis. For them, modern industrialized society is perfectly in order in this respect at least, even if many climate skeptics also express extremely strong criticisms of modern industrialized society and its environmental consumption in other respects. For this reason, they replace "evil" CO2 with "good" $\mathrm{CO}_{2}$, attempting to normalize carbon dioxide and free it from its status as a problematic substance. It is supposed to simply go back to being a "normal" chemical substance as it was before the climate debate. For this reason, climate-skeptic literature always (with a very few exceptions) uses the chemically correct notation, $\mathrm{CO}_{2}$.

The revaluation of the role of carbon dioxide is usually connected in climate-skeptic literature to its role in photosynthesis, drawing on the discovery made by Joseph Priestley and other scientists that carbon dioxide provides basic nutrients for all plants and thus all life. The gas is presented as a force for good: "The astonishing thing is that $\mathrm{CO}_{2}$ is green!"59 After all, it goes hand in hand with life: "Carbon dioxide is not a harmful gas but a useful one, without which there would be no life on earth". ${ }^{60}$ The more $\mathrm{CO}_{2}$, the better: "[woods] are flourishing more than in the past, not least because of the increased level of $\mathrm{CO}_{2}$ in the air". ${ }^{61}$ A moderate climate skeptic from the US agrees: "Human industrial $\mathrm{CO}_{2}$ emissions may be having a modest effect on climate, but they are having a positive effect on plant growth worldwide". ${ }^{2}$ Above all, the one-sided public image of CO2 in climate

\footnotetext{
${ }^{58}$ UK Television, Act on CO2!, 2009, http://wattsupwiththat.com/2009/10/09/uk-television-ad-for-action-on-co2-isbeyond-bad-taste/ (accessed 10 October 2013).

${ }^{59}$ S. Goreham, The Mad, Mad, Mad World of Climatism, foreword by H. Schmitt, New Lenox Books, New Lenox (IL) 2012, p. 3.

${ }^{60}$ G. Krüger, Die Energiewende: Wunsch und Wirklichkeit, Books on Demand, Norderstedt 2012, p. 27.

${ }^{61}$ H. Böttiger, Klimawandel: Gewissheit oder politische Machenschaft?, Michael Imhof Verlag, Petersberg 2008 , p. 7.

${ }^{62}$ R. Zubrin, Merchants of Despair, New Atlantis Books, New York 2012, p. 231.
} 
discourse is criticized: "Greenhouse gases are demonized and carbon dioxide, the lifeblood of a green planet, is redefined as a pollutant by five scientifically challenged liberal activists on the US Supreme Court".63

The passion with which climate skeptics from the USA in particular write about the positive role of carbon dioxide must be viewed against the background of a decision by the US Environmental Protection Agency in December 2009 that categorized carbon dioxide and other greenhouse gases as "pollutants" on the grounds that they have a detrimental effect on the health and prosperity of present and future generations. ${ }^{64}$

In climate-skeptic discourse, other, natural factors replace $\mathrm{CO} 2$ as an explanation for the observed warming, which is accepted as fact by most climate skeptics (though not all). For instance, natural fluctuations of the climate system are posited, as are changes in solar activity.

The necessary counterpart to the attempted normalization of carbon dioxide is the problematization, even the scandalization, of climate research. In other words: climate skeptics do not believe that $\mathrm{CO} 2$ is a hazardous and thus problematic substance, and accordingly they believe that the science which claims this to be the case is itself problematic. In this way, they attempt to strengthen their own standpoint and instigate a scientific discussion, the scope of whose impact many observers consider to be unparalleled in the history of science since the end of the Second World War. ${ }^{65}$ Hence, this conflict needs to be presented in rather more detail. In doing so, I draw primarily on German and English-language sources. Although climate change and its causes are disputed worldwide, ${ }^{66}$ the dispute is especially intense in the German and English-speaking worlds, as can be seen among other things from the number of publications, and can also be well documented thanks to written sources (popular and specialist literature), making the presentation substantially simpler.

\footnotetext{
${ }^{63}$ L. Johnson, Understanding the Global Warming Hoax, Expanded and Updated, Red Anvil Press, Oakland 2009, p. 30 .

${ }^{64}$ Environment Protection Agency, Endangerment and Cause or Contribute Findings for Greenhouse Gases under Section 202(a) of the Clean Air Act, 2009, online at http://www.epa.gov/climatechange/endangerment/ (accessed 10 October 2013).

${ }^{65}$ See among many others P. Kitcher, Science in a Democratic Society, Prometheus Books, Amherst 2011, p. 227: "[climate change] may well be the most significant political question of our age."

${ }^{66}$ For a French-language climate-skeptic work see C. Allègre, D. Montvalon, L' imposture climatique ou la fausse écologie: Conversations avec Dominique de Montvalon, Plon, Paris 2010; L. Cabrol, Climat: Et si la Terre s'en sortait toute seule? Le Cherche-Midi, Paris 2008, including a list of additional literature.
} 


\section{Climate Wars: The Escalation of the Climate Discourse}

Climate skeptics like to use electronic media. Moreover, at least in the USA many of them are organized, though the common conclusion that all climate skeptics are organized and bought-off ${ }^{67}$ is certainly untrue. Although climate-skeptic positions also appear in run-of-the-mill textbooks ${ }^{68}$, they are transmitted to the public in particular through popular non-fiction books. The most influential and most widely disseminated climate-skeptic work is, however, not a pure non-fiction work, but an informative thriller: State of Fear by Michael Crichton, published in 2004 with an initial print run of 1.5 million copies.

Popular climate-skeptic literature doesn't correlate directly with the activities of the IPCC. It manifested only weakly before and after the first three IPCC assessment reports in 1990, 1995, and 2001, when only one or two new climate-skeptic books were published. The figure rose only after the fourth assessment report in 2008 to 11 new publications in the USA and Germany alone ${ }^{69}$, followed by many similar works in subsequent years; in 2010, 20 new popular climate-skeptic works appeared.

But the reason that climate skeptics put pen to paper might have had less to do with this fourth assessment report and more to do with the awarding of the Nobel Peace Prize in 2007 to the IPCC and former US Vice President Al Gore, which enraged and energized the climate skeptics. The fifth assessment report was published at the end of 2013.

The attempts by climate skeptics to normalize $\mathrm{CO} 2$ and problematize climate research can be summarized as follows.

The primary, scientific-theoretical claim is that consensus is not a criterion for truth and that the prevailing view of climate research is nothing more than consensus. ${ }^{70}$ As a historical analogy, the climate skeptics tend to draw on the history of eugenics in the early twentieth century. Eugenics and

\footnotetext{
${ }^{67}$ For instance, the claim (backed up by only a few examples) made by N. Oreskes and E. Conway, Merchants of Doubt: How a Handful of Scientists Obscured the Truth on Issues from Tobacco Smoke to Global Warming, Bloomsbury, New York 2010. See also R.E. Dunlap, A.M. McCright, "Climate Change Denial: Sources, Actors and Strategies", in Routledge Handbook of Climate Change and Society, C. Lever-Tracy (ed.), Routledge, London 2010, pp. 240-259. The most famous and influential climate skeptic is the recently deceased author Michael Crichton, of whom the assumption that he has somehow been paid off is especially implausible.

${ }^{68}$ Well hidden: see for instance J. Schultz, Handbuch der Ökozonen, Verlag Eugen Ulmer, Stuttgart 2000, pp. 209f.

${ }^{69}$ J. Soentgen, H. Bilandzic, "Die Struktur klimaskeptischer Argumentate”, in Gaia, 2014 (forthcoming).

${ }^{70}$ Possibly just a "falsified", forcefully "manufactured" consensus, as the climate skeptic Lindzen puts it. R. Lindzen, "Science and Politics: Climate Science and Eugenics", in From Risks, Costs, and Lives Saved, R.W. Hahn (ed.), Oxford University Press, New York, 1996, pp. 85-103.
} 
the racial theory it was based on were also enthusiastically advocated by a large community of politicians, artists, and researchers as the last resort to escape a looming crisis - there was a broad international and interdisciplinary consensus regarding the truth of the diagnosis at the heart of eugenics that the "Nordic race" was in danger of degenerating due to substandard genetic material. In that instance too, notes the climate skeptic Crichton, there was a broad consensus but a weak scientific basis: "There was no scientific basis for eugenics. In fact, nobody at that time knew what a gene really was."71

The next step is a positive explanation regarding the sociology of science to show how this scientific consensus was able to establish itself. We come here to an aspect of climate-skeptic argument that is normally drawn in broad strokes. Analogously to intuitive toxicology, ${ }^{72}$ one could talk of an intuitive sociology of science. What usually gets presented in such explanations is a type of conspiracy theory that assumes that the public are being deceived by an alliance of climate scientists and politicians. However, because climate research is a social enterprise, this deception can only function as a collective effort, namely as a collaboration between many individuals with the aim of reaching a shared goal by circumventing applicable ethical and/or legal standards, assisted by deliberate deception.

Conspiracy theories are narratively powerful discursive constructs "to explain some event or practice by reference to the machinations of powerful people, who attempt to conceal their role (at least until their aims are accomplished)". ${ }^{73}$ Conspiracy theories are not falsifiable, but instead sufficiently flexible to reinterpret counterarguments and contradictory facts in accordance with their own position. ${ }^{74}$

A threatening situation like climate change, which cannot be fully controlled by even the greatest human efforts and could have considerable consequences for humans, is reinterpreted as a completely different and more easily remedied situation in which a readily identifiable group of people conspire to their own advantage - an occurrence that can be dealt with by normal human

\footnotetext{
${ }^{71}$ M. Crichton, State of Fear, Harper Collins, New York 2004. The phrase "state of fear" is also used by the MIT climate researcher and climate skeptic, Richard S. Lindzen: Lindzen, "Science and Politics" cit.

${ }^{72}$ N. Neill, T. Malmfors, P. Slovic, "Intuitive Toxicology: Expert and Lay Judgments of Chemical Risks", in Toxicologic Pathology, 22, 2, 1994, pp. 198-201.

${ }^{73}$ C.R. Sunstein, A. Vermeule, "Conspiracy Theories: Causes and Cures", in Journal of Political Philosophy, 17, 2 , 2009, pp. 202-227, p. 205; see also J. Grant, Denying Science. Conspiracy Theories, Media Distortions, and the War Against Reality, Prometheus Books, Amherst 2011.

${ }^{74}$ O. Kuhn, "Spekulative Kommunikation und ihre Stigmatisierung - am Beispiel der Verschwörungstheorien: Ein Beitrag zur Soziologie des Nichtwissens”, in Zeitschrift für Soziologie, 39, 2010, pp. 106-123.
} 
methods. Conspiracy theories are thus responses to apocalyptic narratives by climate campaigners, which, although they do not appear in actual scientific literature, are disseminated in public reporting about climate research. ${ }^{75}$ They also have an emotional effect, because they replace feelings like worry and anxiety about a catastrophe it may no longer be possible to avert with passionate anger towards a group of people who are giving others the runaround. For this reason, climate skeptics usually see themselves as serving an enlightening role.

Some authors talk directly of a "global climate agenda", ${ }^{76}$ others initially seem to rule out the possibility of a conspiracy only to then assert one in the very same sentence: "While there is no 'vast green conspiracy' that meets regularly to plot and plan, the disparate groups that comprise the green movement are all working toward a common goal - increased government control of your life."77

There is also often reference to "climate hysteria" and, less commonly, to a new paradigm. ${ }^{78}$ These wouldn't amount to a conspiracy by themselves. But in the view of most climate skeptics, the hysteria, or new paradigm, is something that has been made. In their portrayals of attempts to distort data or silence critics (skeptics), climate skeptics very frequently draw on George Orwell, whose 1984 famously describes systematic methods to enforce conformity: "The relics from the Schnidejoch mock this Orwellian effort to make real-life events that were not politically correct disappear from climate history."79 The conspiracy theorists also include authors who write in an impersonal discursive mode: "This means that the scientific literature is no longer a representation of the state of human knowledge about the climate. It is a representation of what a small cabal of scientists feel is worthy of discussion." 80

Occasionally, science is likened to "the Church", and climate consensus is accordingly presented as

\footnotetext{
${ }^{75}$ P. Weingart, A. Engels, P. Pansegrau, Von der Hypothese zur Katastrophe: Der anthropogene Klimawandel im Diskurs zwischen Wissenschaft, Politik und Massenmedien, B. Budrich, Opladen 2008.

${ }^{76}$ H. Bachmann, Die Lüge der Klimakatastrophe: Der Auftrag des Weltklimaratest; Manipulierte Angst als Mittel zur Macht, 5th ed., Frieling, Berlin 2008.

${ }^{77}$ S. Milloy, Green Hell: How Environmentalists Plan to Control Your Life and What You Can Do to Stop Them, Regnery Publishing, Washington, DC, 2009, p. 235.

${ }^{78}$ P.J. Michaels, R.C. Balling, Jr., The Satanic Gases: Clearing the Air about Global Warming, The Cato Institute, Washington, DC, 2005, pp. 191-198; P. MacRae, False Alarm: Global Warming - Facts versus Fears, Spring Bay Press, Victoria (BC) 2010, pp. 130-150.

${ }^{79}$ H. Svensmark, N. Calder, The Chilling Stars: A Cosmic View of Climate Change, Icon Books, Cambridge 2008, p. 73.

${ }^{80}$ A.W. Montford, The Hockey Stick Illusion: Climategate and the Corruption of Science, Stacey International, London 2010, p. 449.
} 
a "dogma" that represents "the communal faith of the climate religion". ${ }^{81}$ On the other hand, climate skeptics also talk of a "global warming alarmist industry", ${ }^{82}$ which suggests a businessoriented coalition motivated by financial profit.

Climate skeptics will attribute almost anything to the conspiracy, especially fraud on a massive scale: "By means of theoretical calculations, the sun was practically eliminated from climate equations, thereby disqualifying the last competitor to $\mathrm{CO}_{2}$ out of hand." ${ }^{\text {" }}$ "Even worse, the IPCC included in its supplementary material a graph that plotted temperature alongside disaster losses, smoothing the data and scaling the axes in such a way as to suggest a relationship, despite the fact that none had been shown in the peer reviewed literature." 84 "The IPCC was guilty of egregious data manipulation of bending the scientific data for an ulterior motive." 85

Climate researcher Manfred Mann's “hockey stick curve” from the third assessment report in 2001 is repeatedly discussed as an example of data manipulation, because it is claimed that the curve falsifies the climate peak that occurred in medieval times in order to make the recent warming appear more exceptional than it really is. ${ }^{86}$ The emails from the climate researcher and IPCC employee Phil Jones at the Climate Unit of the University of East Anglia that became famous in the wake of the so-called "Climategate scandal" in December 2009 and in which, among other things, Jones recommends a "trick" that he himself had used to process data so that recent temperature measurements indicating a cooling would be less pronounced, are also frequently cited. ${ }^{87}$ It should be noted that an internal review cleared Phil Jones of any scientific wrongdoing.

The conspiracy of climate researchers alleged by climate skeptics is elaborated most dramatically

\footnotetext{
${ }^{81}$ Böttiger, Klimawandel cit., p. 86.

${ }^{82}$ C.C. Horner, Red Hot Lies: How Global Warming Alarmists Use Threats, Fraud, and Deception to Keep You Misinformed, Regnery Publishing, Washington, DC, 2008, p. 340.

${ }^{83}$ F. Vahrenholt, S. Lüning, Die kalte Sonne: Warum die Klimakatastrophe nicht stattfindet, Hoffmann und Campe,
} Hamburg 2012, p. 20

${ }^{84}$ R. Pielke, Jr., The Climate Fix: What Scientists and Politicians Won't Tell You About Global Warming, Basic Books, New York 2010, p. 181.

${ }^{85}$ R.B. Alexander, Global Warming False Alarm: The Bad Science Behind the United Nation's Assertion that ManMade $\mathrm{CO}_{2}$ Causes Global Warming, Canterbury Publishing, Royal Oak (MI) 2009, p. 28.

${ }^{86}$ See Goreham, The Mad, Mad, Mad World cit., pp. 64-69; compare also the account by climate researcher (though not climate skeptic) Hans von Storch: H. von Storch, W. Krauß, Die Klimafalle: Die gefährliche Nähe von Politik und Klimaforschung, Hanser Verlag, Munich 2013, pp. 81-127.

${ }^{87}$ On the credibility crisis of climate research, see also the account in A. Leuschner, Die Glaubwürdigkeit der Wissenschaft: Eine wissenschafts- und erkenntnistheoretische Analyse am Beispiel der Klimaforschung, Transcript, Bielefeld 2012, pp. 73-77, 175-194; the "trick" email is reproduced on p. 201. See also the account by M. Mann, The Hockey Stick and the Climate Wars, Dispatches from the Front Lines, Columbia University Press, New York 2012. 
by the climate skeptic Michael Crichton. In his thriller State of Fear, he imagines a fictional terrorist environmental NGO called the Environmental Liberation Front (ELF) that uses violence to achieve its goals. In the novel, the ELF deliberately causes natural disasters such as a powerful storm in order to give more resonance to a climate conference happening at the same time. However, the hero, accompanied by a group of combat experts, is able just in the nick of time to prevent the ELF from deliberately triggering a tsunami.

For the vast majority of climate-skeptic authors, the IPCC and "climate scientists" are the main villains: they are characterized by climate skeptics as, e.g., "scientists who are ideologically straitjacketed and intoxicated by their political omnipotence". ${ }^{88}$ It is also usually mentioned that climate change generates research funding. ${ }^{89}$ The conspiracy theory now runs into a further problem, namely, that it is highly implausible: why on earth would climate researchers engage in such risky behavior? What do they gain from it? If they know the truth, why would they falsify it?

The climate skeptics have an answer to this too. They could use unemotional explanations, saying for example, that climate science is simply on the wrong path or that it is fixed within its paradigm and ignores therefore the anomalies. But climate skeptics need a more emotional message that is able to evoke anger. They escalate the discourse again and extend the scope of their accusations. The goals of the conspiracy are declared to be money and reputation: "By exaggerating the supposed climate threat, they ensure that state research funding continues to flow abundantly, leading to the founding of new institutes and the creation of new scientific jobs. The postulated climate threat creates career opportunities, prestige, media platforms, and political consultancy roles for climate researchers who had previously been ignored." 90

Moreover, Vahrenholt and Lüning observe in the climate discussion an "increasing tendency not just to ... stick to moral appeals, but to intervene directly in citizens' lives through laws and regulations". ${ }^{91}$ Climate skeptics in the USA usually portray the highly dangerous prospect of a leftwing revolution with green camouflage. The conservative US American journalist Brian Sussman begins his book Climategate - A Veteran Meteorologist Exposes the Global Warming Scam with

\footnotetext{
${ }^{88}$ Vahrenholt, Lüning, Die kalte Sonne cit., p. 336.

${ }^{89}$ G.R. Weber, Treibhauseffekt: Klimakatastrophe oder Medienpsychose? 2nd ed,, Böttiger, Wiesbaden 1992, p. 243.

${ }^{90}$ Vahrenholt, Lüning, Die kalte Sonne cit., p. 274.

${ }^{91}$ Ibid., p. 326.
} 
the sentence: "Global warming’s story begins with a diabolical bastard named Karl Marx."92

In his The Politically Incorrect Guide to Global Warming, the author Christopher Horner pronounces on the modern environmental movement on the very first page: "When communism didn't work out, environmentalism became the anti-capitalist vehicle of choice." ${ }^{\circ 3}$ Hence, in the USA the global warming debate is often seen as part of an "unrelenting war on freedom" led by Marxists. "'Because of its enormous resources, this New Leviathan is able to steer the ship of state into uncharted waters, and to expand its power to the extent that it now threatens the individual liberties that are the heart of the American experiment." 95 Occasionally, it is also claimed that neocolonial impulses for domination are responsible for climate policies: "The atmosphere certainly won't become clean as a result of this kind of energy policy, but backwardness and underdevelopment will be cemented." 96

This covers the most important of the motives imputed by climate skeptics: (1) Climate scientists have conspired to win power and/or secure research funding; (2) climate scientists have conspired to bring about a social reorganization or revolution under a green smokescreen (usually inspired by socialism or communism); (3) climate scientists are agents of a conspiracy of former colonial powers who wish to prevent former colonies that are now industrial nations, such as India or Brazil, from achieving further growth by circuitous routes such as emission reduction policies. ${ }^{97} 75$ percent of the authors of climate-skeptical books use emotional conspiracy theories like these to stigmatize modern climate research. ${ }^{98}$

\section{A Look Ahead: CO2 and the Environment}

\footnotetext{
${ }^{92}$ B. Sussman, Climategate: A Veteran Meteorologist Exposes the Global Warming Scam, WND Books, Washington, DC, 2010, p. ix.

${ }^{93}$ C.C. Horner, The Politically Incorrect Guide to Global Warming and Environmentalism, Regnery Publishing, Washington, DC, 2007, p. 3.

${ }^{94}$ B. Sussmann, Brian, Eco-Tyranny: How the Left's Green Agenda Will Dismantle America, WND Books, Washington, DC, 2012, p. 1.

${ }^{95}$ D. Horowitz, J. Laksin, The New Leviathan: How the Left-Wing Money-Machine Shapes American Politics and Threatens America's Future, Crown Forum, New York 2012, p. 180.

${ }^{96}$ R. Schauerhammer, Sackgasse Ökostaat: Kein Platz für Menschen, Böttiger, Wiesbaden 1990, p. 23; similarly, P. Driessen, Öko-Imperialismus: Grüne Politik mit tödlichen Folgen, TvR Medienverlag, Jena 2006, p. 135.

${ }^{97}$ See also H. Bachram, "Climate Fraud and Carbon Colonialism: The New Trade in Greenhouse Gases”, in Capitalism Nature Socialism, 15, 2004, pp. 1-16.

${ }^{98}$ Soentgen, Bilandzic, "Die Struktur klimaskeptischer Argumentate”.cit.
} 
Despite considerable media activities and some lobbying, the influence of climate skeptics on politics and public opinion has been rather limited to date. There are, admittedly, some unequivocally climate-skeptic politicians, such as the current Australian Prime Minister Tony Abbott, as well as the president of the Czech Republic from 2003 to 2013, Václav Klaus. ${ }^{99}$ The US Republican Party also counts many climate skeptics among its ranks, while, many US climate skeptics cooperate with conservative think tanks. ${ }^{100}$ But the vast majority of politicians in Western industrialized nations accept the causal diagnosis of established climate research.

The history presented here suggests reasons for the low degree of success that climate-skeptic communication has achieved to date in public communication. For one thing, there are strong arguments for the causal diagnosis of science; not for nothing is it regarded by the great majority of climate researchers as the most plausible hypothesis to date. The scientific consensus, however, does not explain the communicative success. This may have been due to the ease with which the causal diagnosis of climate science attaches itself to the everyday concept of gas discussed earlier, which adds emotional efficacy to the diagnosis. Moreover, the negative consequences of the transition to a "low-carbon economy" demanded by climate campaigners, such as increased energy prices or landscapes marred by technology, have hardly been felt so far because although there has been a lot of discussion about climate protection, very few climate protection policies have actually been implemented. And finally, the climate itself has played a certain role (if we can put it that way) inasmuch as global average temperatures, the least contested category of data in the "climate wars", have so far risen somewhat and, more importantly, have not fallen so far. Hence, trust in climate researchers and their statements remains largely intact, especially in Europe, despite a few setbacks.

All these factors contribute to the fact that the environmental discourse is currently still dominated and shaped by the $\mathrm{CO} 2$ debate. It could be said that with the global establishment of the topic of $\mathrm{CO} 2$, a new era of environmental politics has begun, be it only on the symbolic level. CO2 reduction has become nearly synonymous with environmentally friendly activity. The topic of $\mathrm{CO} 2$ has become firmly rooted at the center of the environmental discourse.

Although there are also international panels and international conventions for many other global environmental issues - such as the United Nations Convention to Combat Desertification (UNCCD) or the United Nations Convention on Biodiversity (CBD) - none of these international

\footnotetext{
${ }^{99}$ V. Klaus, Blauer Planet in grünen Fesseln: Was ist bedroht, Klima oder Freiheit? Gerold, Vienna 2007.

${ }^{100}$ P.J. Jacques, R.E. Dunlap, M. Freeman, "The Organisation of Denial: Conservative Think Tanks and Environmental Scepticism, in Environmental Politics, 17, 3, pp. 349-385.
} 
environmental issues are anywhere near as deeply imprinted in public consciousness as the issue of $\mathrm{CO} 2$. Accordingly, there are attempts to translate many traditional natural and environmental issues into $\mathrm{CO} 2$ issues as plausibly as possible. ${ }^{101}$

Since clear measurements of the $\mathrm{CO} 2$ concentration in the atmosphere and good estimates of the quantity of extra carbon dioxide released into the air by human activity are possible, this issue can be integrated with all functional systems in modern society, translated into an economic issue, and made the subject of legal and political endeavors. Because CO2 represents the ashes of all fires, it also makes sense to use it as a measure of our consumption of nature in some important respects. And at the same time, $\mathrm{CO} 2$ is charged with an emotional threat, because as a gas it is difficult to see or grasp. The latent unease in our modern, highly dynamic, but also destructive industrialized society finds expression in this symbol. Perhaps for this reason $\mathrm{CO} 2$ has been able to become the most culturally successful form in which the environment has been thematized in modern society up to now.

\footnotetext{
${ }^{101}$ On this point, see J. Soentgen, “Ökologischer Pluralismus”, in Scheidewege: Jahresschrift für skeptisches Denken,
} 2014 (forthcoming). 